\title{
PERANAN SUNAN AMPEL DALAM DAKWAH ISLAM DAN PEMBENTUKAN MASYARAKAT MUSLIM NUSANTARA DI AMPELDENTA
}

\author{
Nur Hamiyatun \\ UIN Sunan Kalijaga Yogyakarta \\ meycantik07@gmail.com
}

\begin{abstract}
Islam entered the archipelago through several figures called Walisongo. Sheikh Maulana Malik Ibrahim was a leader and pioneer in the field of da'wah who succeeded in forming students to carry out his missions in preaching to the Archipelago and that had happened since the 15th century AD The Walisongo figures I studied were; Sunan Ampel who first came only briefly or stopped by the land of Java with the intention of looking at his aunt until finally settled in Java. Then, the way of preaching carried out by Sunan Ampel by means of da'wah without any element of coercion or the path of peace. Sunan Ampel conducts the spread of Islam in Majapahit with permission from Prabu Brawijaya, so that Sunan Ampel has full rights for Islamization in the Majapahit area. Furthermore, Sunan Ampel established a boarding school in the main door area of the Majapahit kingdom where the Islamic boarding school area is a gift from Prabu Brawijaya. In the preaching carried out by Sunan Ampel, he has several tactics in the spread of Islam that I mentioned above. Then the students who were guided by Sunan Ampel also participated in the spread of Islam in all directions.
\end{abstract}

Keywords : Sunan Ampel, Da'wah and Muslim Ampeldenta

\section{PENDAHULUAN}

Dalam sejarah masuknya Islam ke Nusantara, Walisongo merupakan tokoh perintis awal dakwah Islam di Indonesia, khususnya di Jawa yang dipelopori oleh Syeikh Maulana Malik Ibrahim. Walisongo merupakan pemimpin dan pelopor dalam bidang dakwah yang berhasil dalam membentuk murid-murid untuk menjalankan misi-misi beliau dalam melakukan dakwah ke Nusantara dan itu terjadi sejak abad ke-15 M. Pada umumnya Walisongo ada sembilan wali yang meliputi; Maulana Malik Ibrahim, Sunan Ampel, Sunan Bonang, Sunan Giri, Sunan Kudus, Sunan Drajat, Sunan Muria, Sunan Gunung Jati, dan Sunan Kalijaga. 
Kemudian strata sosial kultural masyarakat Jawa sebelum kehadiran Walisongo sangat dipengaruhi oleh kehidupan yang dikendalikan oleh para pendeta, guru ajar, biksu, wiku, resi, dan empu. Di sini mereka dianggap mempunyai kemampuan mistik dan kharismatik yang kemudian peranan tersebut diambil alih oleh Walisongo untuk penyebaran agama Islam yang tetap berbau mistik religius. Di masa ini juga, merupakan suatu akhir dimana dominasi Hindu-Budha dalam budaya Nusantara digantikan dengan kebudayaan Islam.

Selanjutnya, sebelum mamasuki tema, penulis akan memberi pengertian sedikit tentang makna Walisongo. ${ }^{1}$ Yang mana Walisongo berasal dari kata majemuk yang berasal dari kata wali dan songo. Kata wali berasal dari bahasa Arab, yang mulanya dari kata waliyullah yang berarti "orang yang mencintai dan dicintai oleh Allah". Sedangkan kata songo berasal dari bahasa Jawa yang berarti "sembilan". Sehingga Walisongo di sini memiliki arti “wali sembilan”, atau bisa juga disebut dengan "sembilan orang yang mencintai dan dicintai Allah". Di sini mereka diyakini sebagai ketua kelompok dari sebagian besar mubaligh Islam yang bertugas mengadakan dakwah Islam di daerah-daerah yang belum memeluk Islam di Jawa. ${ }^{2}$

Dari pada itu, penulis akan menjelaskan tema yang meliputi kajian pustaka, latar belakang Sunan Ampel atau asal-usul Sunan Ampel, awal mula Sunan Ampel masuk ke tanah Jawa, Ampeldenta, taktik dan strategi dakwah Sunan Ampel dan Pembentukan Masyarakat Muslim Nusantara terytama di Ampeldenta.

Pembahasan masalah mengenai Peranan Sunan Ampel Dalam Dakwah Islam dan Pembentukan Masyarakat Muslim Nusantara Di Ampeldenta, sepanjang studi pendahuluan yang penulis lakukan, ternyata belum banyak ditemukan apalagi yang menyangkut Peranan Sunan Ampel Dalam Dakwah Islam dan Pembentukan Masyarakat Muslim Nusantara Di Ampeldenta baik yang berupa thesis maupun jurnal. Meskipun ada karya-karya terdahulu cenderung mendeskripsikan secara

\footnotetext{
${ }^{1}$ Pengertian tentag arti dari kata Walisongo di sini memiliki banyak pendapat bahwasannya kata Walisongo tidak melambangkan bahwa jumlah Walisongo ada sembilan melainkan di sini diyakini bahwa ada beberapa periode masa dalam Walisongo yang kemudian memunculkan nama sembilan wali sebagai simbol dari perlambangan, perwalian sembilan orang yang terkenal dan paling luas pengaruhnya terhadap masyarakat. Lihat: Ragil Pamungkas, Teka-teki Walisongo dan 7 Kesalahan Syekh Siti Jenar, Yogyakarta: Armedia, 2008, hal. 212-222.

2 Agus Sunyoto, Atlas Wali Songo: Buku Pertama yang Mengungkap Wali Songo sebagai Fakta Sejarah, Bandung: IIMan, 2012, hal. 109.
} 
umum dan garis besarnya saja, tidak bersifat mendalam dan belum ditemukan penelitian yang membahas secara spesifik dan sistematis sehingga dapat mempermudah pemahaman terhadap kajian Peranan Sunan Ampel Dalam Dakwah Islam dan Pembentukan Masyarakat Muslim Nusantara Di Ampeldenta. Memang dapat dibenarkan bahwa penelitian terhadap Walisongo tersebut sudah banyak yang dilakukan, tapi hanya terhadap bidang yang lain, sedangkan secara khusus tentang Peranan Sunan Ampel. Dalam Dakwah Islam dan Pembentukan Masyarakat Muslim Nusantara Di Ampeldenta belum ada dilakukan. Untuk itulah penelitian ini penulis lakukan, agar mendapat gambaran secara jelas dan fokus tentang Peranan Sunan Ampel Dalam Dakwah Islam dan Pembentukan Masyarakat Muslim Nusantara Di Ampeldenta yang digunakan secara efektif dan efisien untuk mencapai tujuan yang diharapkan. Berdasarkan studi literatur yang telah penulis lakukan, ditemukan beberapa judul penelitian yang berkaitan dengan metodologi ataupun yang berkaitan dengan kedua tokoh tersebut, antara lain:

1. Yuliyatun Tajuddin, dengan judul jurnal, "Walisongo dalam Strategi Komunikasi Dakwah". Pola dan metode dakwah yang digunakan oleh Walisongo dengan perkembangan waktu yang ada telah banyak perbedaan. Penulis di sini ingin mengkaji mengenai pola dakwah Walisongo yang menyesuaikan waktu dan keadaan pada pola pribumisasi kala itu. Pola komunikasi dakwah Walisongo ini bukan dalam bentuk komunikasi mengajak, namun dalam bentuk mengkomunikasikan kebudayaan baru yang memerankan tradisi lama yang telah berlangsung di Nusantara. Pola membangun dialog budaya baru dengan budaya lama inilah yang mempengaruhi pengertian dakwah dalam konteks keindonesiaan. Pengertian dakwah di Nusantara berbeda dengan makna dakwah yang berkembang di kawasan Timur Tengah, yang bermakna mengajak dan menekankan simbol-simbol yang bersifat konfrontatif, agar pihak yang menjadi objek dakwah mengikutinya, baik berlangsung secara paksa maupun berlangsung secara simbolik keagamaan. Secara spesifik, pola dakwah Walisongo didasarkan pada pola pengelolaan dan pengembangan budaya masyarakat. Dalam pengembangan kebudayaan ini, bisa dilakukan dengan memasukkan nilai- 
nilai universal, kearifan lokal, dan ajaran Islam rahmatan lil'alamiin. Berbagai pola kegiatan dakwah mewarnai kehidupan umat sebagai upaya untuk mengiringi perkembangan kehidupan masyarakat. Mengingat kegiatan dakwah bertujuan untuk membentuk dan meningkatkan karakter kepribadian yang baik, yang berakhlakul karimah dan dapat membentuk keseimbangan unsur jiwa sebagai manusia yang berdimensi fisik, psikis, sosial, dan spiritual. ${ }^{3}$

2. Hatmansyah, "Strategi dan Metode Dakwah Wakisongo". Penulis di sini memfokuskan mengenai strategi dan metode dakwah yang dilakukan oleh Walisongo, yang mana strategi yang dilakukan dengan cara, pertama, mengetahui wilayah dakwah, melakukan aktivitas terlebih dahulu yang bisa dikatakan dengan observasi. Kedua, sistem dakwah yang dlakukan dengan cara pengenalan ajaran Islam melalui pendekatan persuasif yang disesuaikan pada situasi dan kondisi masyarakat yang sedang berlangsung. Ketiga, melakukan perang ideologi untuk memberantas etos dan nilai-nilai yang bertentangan dengan aqidah ajaran Islam. Keempat, melakukan pendekatan pada tokoh yang dianggap mempunyai pengaruh pada masyarakat sekitar, tercontoh raja. Kelima, berusaha menguasai kebutuhan-kebutuhan pokok masyarakat baik itu berupa kebutuhan yang bersifat meterial maupun kebutuhan yang bersifat spiritual. Kemudian untuk metode yang digunakan oleh Walisongo, pertama, metode alhikmah, metode yang dilaukan dengan bijaksana seperti mengadakat sekaten, pewayangan, gunungan dan gamelan. Kedua, metode penikahan, jalur ini adalah dakwah dalam mendekatkan keluarga dan perkawinan. Ketiga, mengembangkan pendidikan peantren dilingkungan kerajaan. Keempat, mengembangkan kebudayaan jawa dengan diselipkan ajaran Islam. Kelima, metode dakwah yang melalui sarana dan prasarana perekonomian di masyarakat. Keenam, menggunakan politik sebagai pengembangan dakwa Islam. ${ }^{4}$

3. Muh Fatkhan, "Dakwah Budaya Walisongo: Aplikasi Metode Dakwah Walisongo di Era Multikultural", di sini Muh Fatkhan menyampaikan bahwa faktor yang

${ }^{3}$ Yuliyatun Tajuddin, Walisongo dalam Strategi Komunikasi Dakwah, dalam jurnal Addin, Vol.8, Nomer 02, Agustus 2004.

${ }^{4}$ Hatmansyah, Strategi dan Metode Dakwah Walisongo, dalam jurnal Al-Hiwar, Vol. 03, Nomer 05, Januari-Juni 2015. 
menopang keunggulan dan keistimewaan dari perjuangan Walisongo adalah, menjadikan ajaran Islam mudah untuk digunakan oleh masyarakat sekitar dan mengikuti era yang sedang berlaku. Faktor lain seperti pengetahuan, sifat dan perhatian yang dimiliki oleh Walisongo memang benar-benar konkrit. Agama menjadi multikultural terutama di Jawa karena pendekatan yang digunakan harus melentur dengan masyarakat sekitar dan yang sedang terjadi pada masa tersebut. metode yang digunakan Walisongo seperti metode al-Hikmah, metode yang digunakan oleh Sunan Kalijaga dalam keraiaman sekaten atau syahadatayn (dua kalimat persaksian kunci keislaman), yang dilakukan di Masjid Agung dengan memukul gamelan dengan beberapa langgam yang dimainkan pada waktu bulan Mulud (bulan kelahiran Nabi Muhammad). Metode tadarruj atau tarbiyatun ummah, metode yang digunakan sesuai dengan tingkat pendidikan yang dimiliki oleh masyarakat pada masa tersebut. Sehingga, masyarakat dari segala kalangan menerima tanpa perlawanan serta mengerti apa yang telah disampaikan oleh para Walisongo. ${ }^{5}$

4. Mas'udi, "Genealogi Walisongo: Humanisasi Strategi Dakwah Sunan Kudus". Penulis di sini memfokuskan bahwa Sunan Kudus melakukan metode dakwah melalui humanisasi. Data yang ditunjukkan harus balancing dengan realita sejarah yang terjadi dengan demikian Mas'udi mencoba untuk mengupas bahwa Sunan Kudus menggunakan Humanisasi sistem ibadah sebagai strategi dalam menyebarkan ajaran Islam di tengah-tengah masyarakat pada saat itu. ${ }^{6}$

5. Dewi Evi Anita, “Walisongo: Mengislamkan Tanah Jawa Suatu Kajian Pustaka”. Mengupas mengenai sejarah yang terjadi pada proses pengislaman yang terjadi di tanah Jawa. Peradaban Islam yang masuk ke Nusantara menggunakan cara seperti Nabi Muhammad, seperti perkawinan, perdagangan atau ekonomi dan politik. Hubungan yang muncul menciptakan Islam secara langsung diterima oleh masyarakat pada kala itu. Walisongo juga memiliki kelebihan setiap indivisunya pertama, Sunan Bonang yang mengajarkan ilmu fiqih, tauhid dan tasawuf.

5 Muh Fatkhan, Dakwah Budaya Walisongo: Aplikasi Metode Dakwah Walisongo di Era Multikultural, dalam jurnal Aplikasi Ilmu-ilmu Agama, Vol. 4, Nomer 02, Desember 2003.

${ }^{6}$ Mas'udi, Genealogi Walisongo: Humanisasi Strategi Dakwah Sunan Kudus”, dalam jurnal Addin, Vol. 08, Nomer 02, Agustus 2014. 
Kedua,Sunan Ampel yaang berhasil mendirikan daerah yang berlumpur menjadi daerah yang makmur. Ketiga, Sunan Giri yang mana beliau mendapat julukan sebagai orang yang menciptakan tempat untuk berkholwat serta kramat. Keempat, Sunan Kudus meyebarkan dakwah Islam dengan cara bidang kesenian, seperti mengarang dongeng-dongeng berbasis Islam. Kelima, Sunan Drajat yang dikenal sebagai orang yang memiliki sifat sosial yang tinggi. terlihat dalam sifat beliau dalam perjalanan dakwah membantu rakyat yang sedang sengsara, anakanak yatim piatu, orang sakit dan membantu para fakir dan miskin. Keenam, Sunan Gunung Jati yang mana ilmu agama yang dipelajarinya adalah ilmu syariat, ilmu hakekat, ilmu tarekatt dan ilmu ma'rifat. Beliau merupakan Sunan yang dikenal dengan Sunan berkekuatan magis. Ketujuh, Sunan Kalijaga yang terkenal dengan cara penyebaran dakwah dengan wayang. Kelapan, Sunan Muria, merupakan Sunan yang menyebarkan metode dakwah dengan mengajarkan ajaran tasawuf pada sabtrinya. ${ }^{7}$

Beberapa paparan jurnal di atas menyampaikan tentang Walisongo, perbedaan dengan penulis lakukan adalah belum ada pembaruan mengenai Sunan Ampel yang lebih spesifik. Oleh karena itulah penelitian ini menurut penulis perlu dilakukan dalam rangka membuka wacana baru dalam dunia ilmu pengetahuan, khususnya mengenai Peranan Sunan Ampel Dalam Dakwah Islam dan Pembentukan Masyarakat Muslim Nusantara Di Ampeldenta.

\section{PEMBAHASAN}

\section{Latar Belakang Sunan Ampel}

Sunan Ampel yang bernama asli Ali Rahmatullah, di masa kecilnya bernama Raden Rahmat. Beliau lahir di Campa sekitar tahun 1401 M dan diperkirakan meninggal pada $1467 \mathrm{M}^{8}$ di Demak dan dimakamkan di sebelah barat masjid Ampel,

\footnotetext{
${ }^{7}$ Dewi Evi Anita, Walisongo: Mengislamkan Tanah Jawa suatu Kajian Pustaka", dalam jurnal Wahana Akademika, Vol. 01, Nomer 02 Oktober 2014.

${ }^{8}$ Karena Sunan Ampel wafat sembilan belas tahun setelah uwaknya wafat. Sehingga setelah diperhitungkan berdasarkan tahun wafatnya uwaknya (bibi), yang tertulis pada makamnya $370 \mathrm{H}$ atau 1448/1449 M. Lihat: Widji Saksono, Mengislamkan Tanah Jawa: Telaah atas Metode Dakwah Walisongo, Bandung: Mizan, 1995, hal. 27.
} 
Surabaya. ${ }^{9}$ Dalam cerita Badad Gresik beliau wafat saat sujud di Masjid. Dan beliau dimakamkan di area seluas $1.000 \mathrm{~m} .{ }^{10}$ Kemudian beliau merupakan putra dari Syekh Ibrahim as-Samarkandi. Beliau adalah seorang ulama dari negeri Samarkand (Uzbekistan) yang pada mulanya berdakwah ke Kamboja dan hingga akhirnya menikahi putri kedua Raja Campa yang memiliki dua buah hati yaitu; Sunan Ampel dan Raden Santri, disini terjadi sedikit kesalahpahaman akan nama ayah Sunan Ampel, kemudian untuk memperkuatkan silsilah bahwa Sunan Ampel putra Ibrahim as-Asmarakandi. Maka mata rantai tersebut adalah sebagai berikut: Nabi Muhammad SAW $\rightarrow$ Ali bin Abi Tholib Syadinan Husain $\rightarrow$ Zaenal Abidin $\rightarrow$ Zainal Aliem $\rightarrow$ Zainal Kubra $\rightarrow$ Zainal Khusain $\rightarrow$ Maulana Jumadil Kubra $\rightarrow$ Ibrahim Asmarakandi $\rightarrow$ Ali Rahmatullah. ${ }^{11}$ Sedangkan ibunya, adalah putri kedua Baginda Kiyan. Di sini keberadaan Sunan Ampel tak luput dengan puteri Campa. ${ }^{12}$

Kemudian masa kecil hingga remaja Ali Rahmatullah menghabiskan waktu di Campa, tempat kelahirannya. Kemudian tidak hanya itu, melainkan Ali Rahmatullah juga menimba ilmu agama di Pasai (Lhokseumawe, Aceh). Setelah itu, saat usianya genap 20 tahun, Ali Rahmatullah bersama Ali Murtadho dan Abu Hurairah (adik sepupu Sunan Ampel), diajak oleh sang ayah untuk berkelana ke tanah Jawa untuk berdakwah sekaligus menengok Dewi Andrawati. ${ }^{13}$ Beliau juga merupakan salah satu tokoh yang cerdas dalam bidang pendakwahan salah satu contoh beliau mempunyai taktik sederhana dalam menyebarkan agama Islam, sepertihalnya dalam mengerakkan kader-kader pendakwah yang dididik di pesantren Ampeldenta untuk menikahi putri-putri penguasa bawahan Majapahit, yang bertujuan untuk

9 Mastuki \& M Ishom El-Saha (editor), Intelektualisme Pesantren: Protret Tokoh dan Cakrawala Pemikiran di Era Pertumbuhan Pesantren, Vol.1, Jakarta: Diva Pustaka Jakarta, 2003, hal. 22.

10 Diceritakan bahwa makam Sunan Ampel bersama istri dan lima kerabatnya dipagari baja tahan karat setinggi 1,5 meter, melingkar seluas $64 \mathrm{~m} 2$. Komplek makam tersebut dikelilingi tembok besar setinggi 2,5 meter. Khusus makam Sunan Ampel dikelilingi pasir putih. Lihat: Purwadi, Sejarah Wali Sanga, Yogyakarta: Ragam Media, 2009, hal. 45.

${ }^{11}$ Di sini juga diterangkan banyak silsilah dari macam sumber. Lihat: Agus Sunyoto, Sejarah Perjuangan Sunan Ampel: Taktik dan Strategi Dakwah Islam Di Jawa Abad 14-15, Surabaya: LPLISunan Ampel, 1992, hal. 35-36.

12 Yang mana di sini ibu Sunan Ampel memiliki kakak sulung yang bernama Dewi Sasmitapuri (Dewi Andarawati), dan beliau merupakan permaisuri Prabu Kertawijaya atau Brawijaya I (1447-1451 M). Lihat: Ruslan Arifin Suryo Nugroho, Ziarah Wali: Wisata Spritual Sepanjang Masa, Yogyakarta: Pustaka Timur, 2007, hal. 75-76.

${ }^{13}$ Agus Wahyudi, Silsilah \& Ajaran Makrifat Jawa, Yogyakarta: Diva Press, 2012, hal. 35-36. 
menciptakan keluarga-keluarga Muslim. ${ }^{14}$ Beliau sendiri juga menikahi putri Arya Teja, Bupati Tuban, yang juga cucu Arya Lembu Sura Raja Surabaya yang Muslim. Jejak dakwah Sunan Ampel tidak hanya di Surabaya dan ibukota Majapahit, melainkan meluas ke daerah Sukadana di Kalimantan. ${ }^{15}$

\section{Sunan Ampel Pergi ke Tahan Jawa}

Perjalanan Ali Rahmatullah pergi ke tanah Jawa, mereka sempat singgah dua bulan di Palembang dan berhasil mengislamkan adipati Palembang yang bernama Arya Damar, ${ }^{16}$ setelah itu Ali Rahmatullah dan rombongan melanjutkan perjalanan dengan kapal dan singgah di pelabuhan Jepara hingga akhirnya ke Tuban.

Pada saat itu ayah Ali Rahmatullah menderita sakit dan hingga akhirnya wafat dan dikuburkan di Tuban tepatnya di desa Gresikharjo. Kemudian sepeninggalan ayah tercinta Sayyid Murtadho melanjutkan perjalanan untuk berdakwah keliling Nusa Tenggara, Madura dan sampai ke Bima. Di sini beliau juga mendapat gelar Pandita Bima yang pada akhirnya berdakwah di Gresik dan sering disebut dengan Raden Santri, pada akhirnya Raden Santri meninggal dunia dan dimakamkan di Gresik. Sedangakan, Ali Rahmatullah seorang diri pergi meneruskan perjalanan ke Majapahit menghadap Prabu Brawijaya sesuai dengan niat awal untu menengok uwaknya, Ratu Dwarawati. Kedatangan Sayyid Ali Rahmatullah ke Majapahit diperkirakan abad ke-15. ${ }^{17}$

Setelah Ali Rahmatullah melakukan penyadaran terhadap masyarakat Majapahit yang pada saat itu kondisinya sangat mengenaskan sebagai contoh banyak adipati yang melakukan mabuk, judi dan menikmati hasil pajak dan upeti yang seharusnya untuk istana Majapahit dan lebih sering untuk mereka sendiri terutama digunakan untuk berfoya-foya. Setelah berhasil melakukan penanganan kepada masyarakat Majapahit, Ali Rahamatullah tetap tinggal di Majapahit hingga

${ }^{14}$ Agus Sunyoto, Atlas Wali Songo, hal. 152.

${ }^{15}$ Ibid.

16 Diceritakan dalam hikayat Hasannudin bahwa istri dari Arya Damar merupakan selir dari Prabu Brawijaya V yang mana dalam kondisi hamil diserahkan atau dihadiahkan kepada Arya Damar, yang mana anak dari selir Prabu Brawijaya itu adalah Raden Fatah. Lihat: Purwadi dan Enis Niken, Dakwah Wali Songo: Penyebaran Islam Berbasis Kultur di Tanah Jawa. Yogyakarta: Panji Pustaka Yogyakarta, 2007, hal. 24.

17 Agus Sunyoto, Atlas Wali Songo, hal. 153-154. 
setahun di Majapahit. Kemudian Ali Rahmatullah menikah dengan putri cantik yang bernama Nyai Ageng Manila (Ni Gede Manila), anak perempuan Tumenggung Wilatika. Dari hasil pernikahan ini Ali Rahmatullah memiliki empat buah hati yaitu; Putri Nyai Taluki yang bergelar Nyai Ageng Maloka, Maulana Makdum Ibrahim (sunan Bonang), Syarifuddin (Sunan Drajat), dan Dewi sarah. ${ }^{18}$

Menurut sejarah Ali Rahmatullah memiliki dua orang istri yang pertama istri yang dinikahi waktu perajanan dari Tuban ke Kembang Kuning dan Wonokromo. Yang bernama Mas Karimah putri Ki Wiryo Suryo atau Ki Wirajaya atau lebih terkenal dengan julukan Ki Bang Kuning. Dari hasil pernikahan ini beliau memiliki tiga buah hati yaitu; Mas Murtosiyah, Raden Patah (Adipati Demak), dan Mas Murtosimah. ${ }^{19}$

Setelah beberapa saat di Majapahit, Ali Rahmatullah menyelesaikan tugasnya hingga akhirnya Ali Rahmatullah diberi tanah di Ampeldenta, Surabaya. Sejumlah 300 keluarga diserahkan untuk dididik dan mendirikan pemukiman di Ampel. Meskipun raja Majapahit menolak untuk masuk Islam, namun Rahmatullah diberikan suatu kemudahan dalam penyebaran Islam terhadap warga Majapait tanpa ada paksaan apapun.

\section{Ampeldenta}

Daerah Ampeldenta yang berawa-rawa merupakan hadiah dari Raja Majapahit, di sini Ali Rahmatullah membangun dan mengembangkan pondok pesantren. Mula-mula beliau merangkul masyarakat sekitar. Dakwah pertama kalinya sangatlah unik, beliau membuat kerajinan yang berbentuk kipas yang terbuat dari akar-akar tumbuhan dan ayamanan rotan. Kipas-kipas ini dibagiakan secara gratis kepada masyarakat sekitar. Hanya tetapi, penduduk cukup mengucapkan kalimat syahadat. Kipas-kipas ini bukanlah kipas-kipas sembarangan melainkan kipas yang juga berfungsi sebagai obat demam dan batuk. ${ }^{20}$ hal. 53.

${ }^{18}$ Feby Nurhayati, dkk., Wali Sanga: Profil dan Warisannya, Yogyakarta: Pustaka Timur, 2007,

\footnotetext{
${ }^{19}$ Agus Sunyoto, Atlas Wali Songo, hal. 163.

${ }^{20}$ Purwadi dan Enis Niken, Dakwah Wali Songo, hal. 24-25.
} 
Dari sini awal mula dakwah Ali Rahmatullah mulai berkembang dengan banyaknya masyarakat yang masuk Islam. Yang kemudian membangun sebuah langgar untuk tempat pendakwahan yang berkembang terus menurus. Hingga pada akhirnya membangun sebuah pondok pesantren yang pada abad ke-15, pesantren ini menjadi sentra pendidikan yang sangat berpengaruh di wilayah Nusantara, bahkan Mancanegara. Diantara santri beliau pada saat itu, Sunan Giri dan raden Patah yang menyebarkan dakwah Islam ke Jawa dan Madura. ${ }^{21}$

Pada awalnya sistem pondok pesantren Ampel ini merupakan pengembangan dari kebudayaan pra Islam yang pertama kali dipelopori oleh Syekh Maulana Malik Ibrahim. Tetapi, Ali Rahmatullah dianggap paling berhasil dalam mendidik ulama dan mengembangkan pesantren, dan dalam waktu singkat nama Ampeldenta sudah terkenal ke semua penjuru belahan bumi. ${ }^{22} \mathrm{Di}$ sini pesantren Ampeldenta mengalami pesatnya pertumbuhan dan perkembangan yang didukung oleh faktor letak Ampeldenta yang strategis. ${ }^{23}$ Hingga akhirnya Ampeldenta menjadi sentra pendidikan Islam yang paling berpengaruh di tanah Jawa. ${ }^{24}$ Kemudian, sejalan dengan Islamisasi yang beliau lakukan, Sayyid Ali Rahmatullah juga terkenal sebagai arsitek utama masjid Demak (1479 M). Yang dimana masjid Demak digunakan sebagai tempat berkumpul para Wali dalam mendiskusikan bagaimana cara dakwah terhadap masyarakat terutama persoalan adat istiadat yang dipegang masyarakat sekitar. Hingga pernah suatu kali Sunan Ampel berdebat dengan Sunan Kalijaga tentang metode dakwah. ${ }^{25}$

Kemudian Raden Rahmat di sini memang dikenal memiliki kepekaan adaptasi, dapat dilihat dari cara beliau menamankan akidah dari syariat yang

${ }^{21}$ Mastuki Hs \& M. Ishom El-Saha (editor), Intelektualisme Pesantren, hal. 23.

22 Agus Sunyoto, Sejarah Perjuangan Sunan Ampel, hal. 46.

${ }^{23}$ Letak dari desa Ampeldenta yang berada di tepi sungai dan pelabuhan Surabaya atau bisa dibilang letak Ampeldenta berada di pintu gerbang utama Majapahit, maka Ampel mau tidak mau harus bersinggungan lansung dengan sikrulasi perkembangan perdagangan Majapahit karena seluruh kapal dari dan ke Majapahit itu harus melewati sungai dan pelabuhan Surabaya. Hal ini membuat mudah Sunan Ampel dalam memanfaatkan misi dakwahnya kepada para bangsawan, pedangan maupun pegawai kerajaan yang melewati wilayahnya itu. Ibid.

${ }^{24}$ Ibid.

25 Metode dakwah yang dipertentangkan antara pendapat Sunan Ampel yang menyebarkan dakwah dengan cara monoton dengan pendapat Sunan Kalijaga yang ingin menyebarkan Islam dengan cara memasukan Islam kepada kebudayaan lama mereka atau tradisi lama. Lihat: Feby Nurhayati, dkk., Wali Sanga, hal. 54. 
memperhatikan kondisi masyarakat. Kata "shalat" diganti dengan "sembahyang" (asalnya: sembah dan nyang). Tempat ibadah juga tidak dinamai mushola melainkan “langgar", mirip dengan kata "sanggar". Kemudian orang penuntut ilmu diberikan nama santri, yang berasal dari shastri (orang yang tahu buku suci agama Hindhu). ${ }^{26}$

Hingga nama beliau berganti menjadi Sunan Ampel sesuai dengan tempat dimana beliau menyebarkan dakwah. Sunan Ampel menganut fikih Mahzab Hanafi. ${ }^{27}$ Namun, beliau menyampaikan kepada santri-santrinya dengan lima dasar yang sederhana pada peenamaan aqidah dan ibadah. Ajaran yang terkenal dengan falsafah atau istilah itu adalah "moh limo artinya: tidak melakukan lima hal yang tercela. Yakni (moh main), (moh ngombe), (moh maling), (moh madat), (moh madon) ", yaitu seruan untuk "tidak berjudi, tidak minum-minuman keras, tidak mencuri, tidak mengunakan narkotika, dan tidak berzina". ${ }^{28}$

Sunan Ampel yang sangat terkenal dalam penyampaiankan dakwah. Beliau merupakan seseorang yang pandai dalam hal menarik dan memikat hati pendengar, ini dapat ditunjukan dengan beberapa nasehat yang beliau sampaikan: ${ }^{29}$

Sapa kang mung ngakoni barang kang kasat mata wae, iku durung weruh jatining Pangeran, yen sira kasinungan ngelmu kang marakake akeh wong seneng, aja sira malah rumangsa pinter jalaran manawa Gusti mundhut bali ngelmu kang marakake sira kaloka iku, sira uga banjur kang wong sajane, malah bisa aji godhong jati aking, sig sapa gelem gawe seneng marang liyan, iku bakal oleh welas kang luwih gedhe katimbang apa kang wis ditindakake.

Artinya: " barang siapa yang mengakui barang yang terlihat oleh mata saja, itu berarti belum mengerti Tuhan, jikalau engkau mempunyai ilmu yang menyebabkan banyak orang yang suka kepadamu, janganlah engkau merasa paling pandai, sebab kalau Tuhan mengambil kembali ilmu yang menyebabkan engkau tersohor itu, engkau akan menjadi tak berbeda dengan yang lainnya, bahkan nilainya menjadi di bawah nilai daun jati yang sudah kering, barangsiapa suka membuat senang orang

\footnotetext{
${ }^{26}$ Purwadi, Sejarah Wali Sanga, hal. 25.

27 Raden Rahmat disini menganut mahzab Hanafi yang terkenal keras, namun Raden Rahmat tetap toleran pada mahzab penganut lainnya dan tidak pernah mempermasalahkan perbedaan mazhab tersebut. Bahkan beliau juga membebaskan para pengikutnya mengikuti mahzab apa saja dan tetap bersikap netral. Beliau juga lebih mengutamakan segi penanaman akidah dan pelaksaan syariat yang disesuaikan dengan situasi dan kondisi yang ada, sehingga mendapat simpati dari baebagai kalangan. Ibid.

${ }^{28}$ Mastuki Hs \& M. Ishom El-Saha (editor), Intelektualisme Pesantren, hal. 23.

${ }^{29}$ Purwadi, Sejarah Wali Sanga, hal. 27-28.
} 
lain, maka ia akan mendapat balasan yang lebih banyak daripada yang ia lakukan."

Sunan Ampel menyampaikan nasehat yang berarti bahwa orang yang memiliki ilmu adalah orang yang bermanfaat untuk yang lainnya. Tidak ada sifat sombong, ujub serta pamer dalam kepemilikan sifat tersebut. Sehingga, apabila masyarakat melakukan hal tersebut mereka faham bahwa mereka mengenal Allah dengan kiasan barang siapa mengenal dirinya maka la juga akan mengenal Tuhannya, dengan demikian Allah akan memberikan kedudukan yang hakiki sebagai sahabatnya, sebagai orang alim yang bersama dengan Allah. Sunan Ampel juga menyatakan bahwasanya sistem pahala yang berkali lipat apabila kita melakukan kebaikan akan dibalas oleh Allah, hal tersebut menarik hati masyarakat pada kala itu.

\section{Taktik dan Strategi Dakwah Sunan Ampel}

Dalam menyebarkan agama Islam, Sunan Ampel menggunakan cara pendekatan kultur kebudayaan karena masih banyak masyarakat yang menganut kuat kepercayaan lama. Sehingga mengunakan budaya yang sudah dikenal masyarakat dan mengisinya dengan ajaran Islam. Cara pendekatan dakwah Sunan Ampel di Jawa dengan cara menyesuaikan diri, menyerap, bersikap pragmatis dan menempuh cara yang berangsur-angsur. ${ }^{30}$

Sunan Ampel mengembangkan pendidikan pesantren dengan kecerdasan dan kedalamaan ilmu agama yang dimilikinya. Dengan, sistem pendidikan Islam yang mengambil bentuk lembaga pendidikan biara dan asrama yang dipakai pendeta dan biksu yang mengajar dan belajar. Oleh sebab itu, pesantren di masa itu memakai mandala-mandala Hindhu-Budha yang pengaruhnya masih terlihat sampai saat ini. Langkah yang di tempuh Sunan Ampel ini merupakan langkah persuasiedukatif dalam proses perkembangan Islam terhadap masyarakat setempat agar

30 Metode dakwah yang berangsur-angsur dikatakan bahwa Islam di Indonesia (Jawa-pen) bersifat fabian (menghendaki perubahan yang berangsur-angsur). Metode dakwah Walisongo dalam bidang pendidikan, budaya, tasawuf dan politik semuanya dibalut akan kultur lama masyarakat, sehingga Islam mudah diterima dan cepat berkembang dengan pesat. Lihat: Feby Nurhayati, dkk., Wali Sanga, hal. 102-103. 
masyarakat setempat mudah untuk menerima nilai-nilai Islam. Dan berbagai istilah yang digunakanpun masih berkaitan dengan ritual-ritual Hindhu-Budha. ${ }^{31}$ Kemudian, tempat pesantren Sunan Ampel tidak pernah membatasi seseorang yang menutut ilmu dari penjuru dunia belajar kepadanya. Kemudian letak Ampeldenta yang strategis juga yang memungkinkan cepatnya berita yang diterima baik itu dari dalam maupun luar Jawa.

Kemudian, Sunan Ampel juga pernah menarik perhatian banyak orang dari segala penjuru dengan mengubah nama sungai Brantas yang menuju ke Surabaya dengan nama Kali Emas dan pelabuhan Surabaya pun diganti nama juga dari Jelangga Manik menjadi pelabuhan Tanjung Perak. Dengan nama Emas dan Perak inilah yang menyebabkan banyak orang yang berbondong-bondong datang ke Surabaya untuk mencari Emas dan Perak. Pada waktu orang-orang yang mencari Emas dan Perak itu datang ke Surabaya, waktu itulah yang digunakan Sunan Ampel untuk memberikan pengertian dan memperkenalkan Islam. 32

Ajaran Islam yang tidak pernah membedakan pangkat, keturunan, kekayaan, maupun kebangsaan seseorang yang menjadikan pesantren Ampeldenta sebagai satu-satunya lembaga pendidikan di Jawa yang diikuti oleh seluruh kalangan masyarakat. Sunan Ampel tidak berhenti sampai di sini saja melainkan juga melebarkan sayap di bidang dakwah untuk menyebarkan ajaran Islam. Oleh sebab itu, Sunan Ampel melihat kemungkingan terbaik adalah dengan mendidik kaderkader ulama yang siap berdakwah di dareah pendalaman Jawa. 33 Dalam penyebaran para ulama yang memungkinkan untuk melakukan dakwah, Sunan Ampel memberikan satu strategi dalam rangka berdakwah. Adapun langkah-langkah yang harus ditempuh ketika itu adalah: ${ }^{4}$ pertama, membagi wilayah inti kerajaan Majapahit sesuai hirarki pembagian wilayah negara bagian yang ada yang meliputi Sembilan wilayah, yakni ibukota Majapahit di Trowulan, Daha, Blambangan, Matahun, Tumapel, Kahurupan, Lasem, Wengker, dan Panjang. Para kader ulama yang akan dikirim ke negara-negara bahawan Majapahit yang memungkinkan

\footnotetext{
${ }^{31}$ Agus Sunyoto, Sejarah Perjuangan Sunan Ampel, hal. 52

${ }^{32}$ Ibid., hal. 53.

${ }^{33}$ Ibid.

${ }^{34}$ Ibid., hal. 53-54.
} 
dimasuki. Kedua, sistem dakwah dilakukan dengan pengenalan ajaran Islam melalui pendekatan persuasive yang berorientasi pada penanaman akidah Islam yang disesuiakan dengan situasi dan kondisi yang ada. Ketiga, melakukan "perang Ideologi" untuk memberantas mitos dan nila-nilai dogmatis yang bertentangan dengan akidah Islam, di mana pura ulama harus menciptakan mitos dan nilai-nilai tandingan baru yang sesuai dengan Islam. Keempat, berupaya dalam melakukan pendekatan kepada tokoh-tokoh yang dianggap mempunyai pengaruh di suatu tempat, dan berusaha menghindari konflik. Kelima, berusaha menguasai kebutuhankebutuhan pokok yang sangat dibutuhkan masyarakat, baik itu kebutuhan yang bersifat material maupun spriritual.

Selain dengan dengan cara dakwah yang dipaparkan di atas, Sunan Ampel juga telah menggunakan cara berdakwah yang diterangkan dalam catatan historiografi lokal diketahui sebagai tokoh yang menjalankan amanat agama itu dengan sangat baik melalui prinsip dakwah maw'izhatul hasanah wa mujadalah dillati hiya ahsan. Sebagaimana dicontohkan oleh Nabi Muhammad SAW dalam usaha dakwah yang dilakukan Raden Rahmat adalah membentuk jaringan kekerabatan melalui perkawinan-perkawinan para penyebar Islam dengan putri-putri penguasa bawahan Majapahit. Dengan demikian, ikatan kekeluargaan di antara umat Islam menjadi kuat. 35

Sejarah dalem bahwa putri Arya Lembu Sura menikah dengan penguasa Tuban Arya Teja, dan menurunkan bupati-bupati Tuban. Disebutkan pula bahwa putri Arya Lembu Sura yang lain yang bernama Retna Panjawi menikah dengan Prabu Brawijaya dari Majapahit. Lewat tokoh Prabu Brawijaya yang menikahi bibi Raden Rahmat, hubungan dengan Arya Lembu Sura terjalin. Itu sebabnya, setelah Prabu Brawijaya menyerahkan Raden Rahmat kepada penguasa Surabaya yang beragama Islam yang kemudian dinikahkannya Raden Rahmat dengan Nyai Ageng Manila, hal inilah yang menjadikan Raden Rahmat mendapatkankan kedudukan sebagai Bupati yang mana Raden Rahmat menjadi bupati pertama dalam daftar urutan bupati-bupati Surabaya sebagai berikut: punika panjenenganing kabupaten

\footnotetext{
${ }^{35}$ Agus Sunyoto, Atlas Wali Songo, hal. 158.
} 
surapingga/kanjeng sinuhun ngAmpeldenta/nami pangeran rahmat/juluk sek mahdun/seda krasarekaken ing ngampel//. ${ }^{36}$

Apalagi didukung oleh kedudukan sebagai bupati yang berkuasa disuatu wilayah, dikarenakan akan lebih leluasa dalam memperkuat jaringan kekerabatan dengan penguasa-penguasa wilayah lainnya. Contohnya Sunan Ampel menikahkan Khalifah usen (nama tempat di Rusia Selatan di deket Samarkand-pen) dengan putri Arya Baribin, Adipati Madura. 37

"kocapa maolana saking Ngatas Angin/ pan kalipah Usen namanira/ pan sampun prapta ing Ngempel/ sampun lami tinuduh marang susuhunan ing Ngampel Geding/ dadya imam Madura lan Sumenep/ Belego lan Surawesti/ kalipah Usen Kobra kambil mantu mring Arya Baribin// " Yang artinya: "tersebutlah seorang maulana dari negeri Atas Angin/bernama Khalifah Usen/telah datang ke Ampel/telah lama ditunjuk oleh Sunan Ampel/untuk menjadi imam di Madura dan Sumenep/Mengislamkan semua orang Madura hingga Sumenep/balega dan Surabaya/Khalifah Usen Kubra diambil menantu oleh Arya Baribin".

Tidak hanya melalui jalur pernikahan saja, melainkan Raden Rahmat mengajarkan murid-muridnya membaca al-Qur’an kemudian membaca kitab-kitab tentang ilmu syariat, tarekat, dan ilmu hakikat, baik itu dari segi lafal maupun makna. Raden Rahmat juga mencontohkan kehidupan zuhud dengan melakukan riyadhah ketat. Badab Tanah Jawi mengambarkan amaliyah rohani yang dijalankan Sunan Ampel sebagai berikut. ${ }^{38}$

Ora dhahar ora guling/anyegah ing hawa/ora sare ing wengine/nibadah maring Pangeran/fardhu sunat tan ketinggal/sarwa nyegah haram nakruh/tawajuhe muji ing Allah//.

Artinya: tidak makan tidak tidur, mencegah hawaa nafsu/tidak tidur malam untuk bertbadah kepada Tuhan/fardhu dan sunnah tak ketinggalan/serta mencegah yang haram maupun yang makruh/tawajuh memuji Allah//.

Terdapat banyak hal yang dilakukan Sunan Ampel untuk kawasan Ampeldenta, yang mana awal mula tempat tersebut adalah rawa yang tidak

\footnotetext{
36 Ibid.

37 Agus Sunyoto, Wali Songo: Rekonstruksi Sejarah yang Disingkirkan, Jakarta: Transpustaka, 2011, hal. 113.

${ }^{38}$ Ibid.
} 
perpenguhi. Sunan Ampel berhasil dalam penyebaran Islam yang dilakukan dengan faktor yang telah disebutkan di atas serta beliau mampu dalam memikat hati para masyarakat sekitar dengan apa yang beliau miliki. Pendidikan, pengetahuan, ekonomi, dan pondok pesantren menjadi perkembangan yang bagus. Sunan Ampel mengajarkan pengetahuan yang tingkatan paling awam hingga, pengetahuan yang dimiliki para bangsawan. Posisi, kedudukan dan pengetahuan yang dimiliki Sunan Ampel pula yang berpengaruh akan penyebaran agama Islam di Ampeldenta.

\section{Pembentukan Masyarakat Muslim Nusantara Terutama di Ampeldenta}

Dakwah yang dimulai dengan jalur pernikahan membuahkan hasil yang mana seluruh keuasaan berada di tangan Sunan Ampel. Karakter masyarakat muslim di Nusantara terlihat terutama di daerah Ampeldenta, banyak pondok pesantren besar yang berasal dari Jawa Timur. Tidak hanya hal tersebut Sunan Ampel memberikan perubahan dalam menerapkan hak, tanggung jawab yang baik sebagai masyarakat Islam. Pembentukan tersebut menjadi beberapa hal seperti pertama, pembentukan individu yang bertanggung jawab, baik dari sisi jasmani dan rohani dengan menghindarkan diri dari menjahui minuman arak, beristri dengan secukupnya.

Kedua, pembentukan karakter dari segi keluarga, Sunan Ampel memberikan contoh atas keharmonisan serta sikap sehari-hari bersama sang istri. Memenuhi keperluan keluarga, seperti nafkah sehari-hari makan, minum dan lain-lainnya. Sunan Ampel memberi contoh menjadi suami yang bertangung jawab atas keluarga yang dibina dengan memberikan pendidikan Islam yang sempurna. Selain, kebutuhan tersebut Sunan Ampel membina keluarganya dengan baik dan sempurna, memperlakukan secara adil.

Ketiga, Sunan Ampel juga memberikan contoh agar menghargai hak orang lain untuk hidup, karena pada dasarnya manusia merupakan orang yang berharga, nyawa yang berharga utuk keluarganya masing-masing. Sunan Ampel memberikan pengetahuan yang cukup pada masyarakat sekitar baik dari segi ekonomi, kesehatan dan keluarga. Sunan Ampel menerapkan sifat toleransi antara semua manusia, bahwa masnusia memiliki hak yang sama. Sehingga tidak ada nilai sifat 
yang memperburuk atau mencela antara sesama umat. Dengan demikian, kehidupan di Ampeldenta menjadi harmonis, walaupun hasil yang telah ditorehkan oleh Sunan Ampel banyak yang tidak suka dan mencoba untuk mempengaruhi masyarakat pada saat itu.

Keempat, Sunan Ampel memberikan kebebesan berfikir dan menyatakan pendapat, kebebasan bergerak sebagaimana tempat di mana ia tinggal. Dengan demikian Sunan Ampel dapat memastikan umat muslim di Ampeldenta pada saat itu menjadi manusia yang berpribadi yang baik sesuai dengan syariat yang diajarakan Islam. Sunan Ampel juga menengakkan perkara yang makrufdan mencegah yang mungkar.

Kelima, memberikan hak kepada semua kalangan masyarakat untuk mencapai pendidikan Islam. Pendidikan yang didapatkan tidak dibedakan setiap kalangan semua ilmu pengetahuan yang diberikan sama sesuai dengan tingkatan yang dimiliki oleh masyarakat Ampeldenta.

Keenam, ajaran ilmu tasawuf seperti bersabar, berpuasa, menjahui diri dari keramaian, harta benda Sunan Ampel contohkan dalam keseharian yang beliau lakukan. Murid-murid beliau juga memahami cara membaca al-Qur'an dengan baik, dan pengetahuan seperti ilmu syari'at, hakikat Sunan Ampel berikan pada muridnya. Murid Sunan Ampel yang telah menguasai ilmu yang diberikan oleh Sunan Ampel melakukan pendakwaan atau penyebaran ilmu agama Islam yang berbasic pesantren. Sehingga Sunan Ampel dinyatakan sebagai Walisongo yang yeng berperan dalam adanya pesantren di Nusantara.

\section{KESIMPULAN}

Walisongo merupakam suatu fenomena yang sangat menarik untuk dibahas, khususnya untuk masyarakat Indonesia. Walaupun penyebarannya hanya dilakukan di tanah Jawa tapi pengaruhnya dirasakan hingga seluruh Nusantara. Dampak yang kita rasakan bersama atas dakwah Walisongo sepertihalnya hampir seluruh masyarakat Indonesia yang beragama Islam melakukan ziarah ke tempat-tempat Walisongo. 
Selanjutnya, tokoh Walisongo yang dikaji yaitu; Sunan Ampel yang mula-mula datang hanya sebentar atau mampir ke tanah Jawa dengan niatan menengok bibinya hingga akhirnya menetap di tanah Jawa. Kemudian, cara dakwah yang dilakukan Sunan Ampel dengan cara dakwah tanpa ada unsur paksaan sedikitpun atau jalur damai.

Di sini Sunan Ampel melakukan penyebaran Islam di Majapahit dengan seizin Prabu Brawijaya, sehingga Sunan Ampel memiliki hak penuh untuk pengislaman di daerah Majapahit. Selanjutnya, Sunan Ampel mendirikan suatu pondok pesantren di area pintu utama kerajaan Majapahit yang mana daerah pondok pesantren tersebut merupakan suatu hadiah dari Prabu Brawijaya. Dalam dakwah yang dilakukan Sunan Ampel, beliau memiliki beberapa taktik dalam penyebaran Islam. Kemudian santrisantri yang dibimbing oleh Sunan Ampel juga ikut melakukan penyebaran agama Islam di segala penjuru.

Dilanjutkan dengan realita-realita yang ada dapat kita tarik kesimpulan bersama bahwasanya Sunan Ampel, merupakan tokoh Walisongo yang mengembangakan sistem pondok pesantren yang berpengaruh di tanah Jawa. Kemudian Sunan Ampel juga menggunakan cara pendekatan-pendekatan kulturan yang ada dan berkembang pada saat itu. Hingga pada akhirnya Islam mempunyai daya tarik tersendiri dan cara yang dipakai oleh Sunan Ampel ini merupakan cara yang melenturkan Islam terhadap kebudayaan yang ada, tanpa ada perubahan yang dilakukan. Inilah beberapa hal yang terdapat dalam dakwah Sunan Ampel, hingga kita bisa memepelajari bersama bahwasanya Islam itu suatu agama yang indah dan sangat ramah lingkungan sehingga tidak ada unsur paksaan sedikitpun dalam kita beragama. 


\section{REFERENSI}

Anita, Dewi Evi, Walisongo: Mengislamkan Tanah Jawa suatu Kajian Pustaka”, dalam jurnal Wahana Akademika, Vol. 01, Nomer 02 Oktober 2014.

Fatkhan, Muh, Dakwah Budaya Walisongo: Aplikasi Metode Dakwah Walisongo di Era Multikultural, dalam jurnal Aplikasi Ilmu-ilmu Agama, Vol. 4, Nomer 02, Desember 2003.

Hatmansyah, Strategi dan Metode Dakwah Walisongo, dalam jurnal Al-Hiwar, Vol. 03, Nomer 05, Januari-Juni 2015.

Mastuki Hs \& M. Ishom El-Saha (editor), Intelektualisme Pesantren: Protret Tokoh dan Cakrawala Pemikiran di Era Pertumbuhan Pesantren, Vol.1, Jakarta: Diva Pustaka Jakarta, Juni 2003.

Nugroho, Ruslan Arifin Suryo, Ziarah Wali: Wisata Spritual Sepanjang Masa, Yogyakarta: Pustaka Timur, September 2007,

Nurhayati, Feby, dkk., Wali Sanga: Profil dan Warisannya, Yogyakarta: Pustaka Timur, September 2007,

Pamungkas, Ragil, Teka-teki Walisongo dan 7 Kesalahan Syekh Siti Jenar, Yogyakarta: Armedia, 2008,

Purwadi dan Enis Niken, Dakwah Wali Songo: Penyebaran Islam Berbasis Kultur di Tanah Jawa. Yogyakarta: Panji Pustaka Yogyakarta, Febuari 2007,

Purwadi, Sejarah Wali Sanga, Yogyakarta: Ragam Media, 2009,

Saksono, Widji, Mengislamkan Tanah Jawa: Telaah atas Metode dakwah Walisongo, Bandung: Mizan, 1995,

Sunyoto, Agus, Atlas Wali Songo: Buku Pertama yang Mengungkap Wali Songo sebagai Fakta Sejarah, Bandung: IIMan, 2012, , Sejarah Perjuangan Sunan Ampel: Taktik dan Strategi Dakwah Islam Di Jawa Abad 14-15, Surabaya: LPLI-Sunan Ampel, 1992, , Wali Songo: Rekonstruksi Sejarah yang Disingkirkan, Jakarta: Transpustaka, 2011, 
Nur Hamiyatun

Tajuddin, Yuliyatun, Walisongo dalam Strategi Komunikasi Dakwah, dalam jurnal Addin, Vol.8, Nomer 02, Agustus 2004.

Wahyudi, Agus, Silsilah \& Ajaran Makrifat Jawa, Yogyakarta: Diva Press, Maret 2012, 